\title{
Purchase Intention Produk Smartphone ditinjau dari Aspek Brand Management
}

\author{
Acai Sudirman* \\ Program Studi Manajemen Sekolah Tinggi Ilmu Ekonomi Sultan Agung \\ Jl. Surabaya No.19, Kota Pematang Siantar, Indonesia \\ acaivenly@stiesultanagung.ac.id \\ Andy Wijaya \\ Program Studi Manajemen Sekolah Tinggi Ilmu Ekonomi Sultan Agung \\ Jl. Surabaya No.19, Kota Pematang Siantar, Indonesia \\ andywijaya@stiesultanagung.ac.id

\section{Sherly} \\ Program Studi Manajemen Sekolah Tinggi Ilmu Ekonomi Sultan Agung \\ Jl. Surabaya No.19, Kota Pematang Siantar, Indonesia

\section{sherly@stiesultanagung.ac.id}

\section{Firia Halim} \\ Program Studi Manajemen Sekolah Tinggi Ilmu Ekonomi Sultan Agung \\ Jl. Surabaya No.19, Kota Pematang Siantar, Indonesia \\ fitriahalim2839@stiesultanagung.ac.id
}

\section{Anju Bhernadetha Nainggolan}

Program Studi Manajemen Universitas Efarina

Jl. Pendeta J.Wismar Saragih, Kota Pematang Siantar, Indonesia nainggolan.anju@gmail.com

Diterima: 09-02-2021

Disetujui: 16-06-2021

Dipublikasi: 30-06-2021

\begin{abstract}
ABSTRAK
Perilaku belanja online dan belajar online menggunakan perangkat elektronik seperti smartphone saat ini menjadi fenomena yang menarik di Indonesia. Penggunaan smartphone yang terus meningkat tajam tentunya tidak terlepas dari peran brand management produk smartphone tersebut. Penelitian ini bertujuan untuk menganalisis peran brand experience, brand awareness, brand visibility dan brand reputation dalam mendorong purchase intention pada generasi Z. Penelitian ini menggunakan desain penelitian dengan pendekatan kuantitatif. Data dikumpulkan melalui dokumentasi dan penyebaran kuesioner secara online. Penelitian ini menggunakan sampel sebanyak 180 responden dengan penentuan ukuran sampel memakai rumus sampling purposive. Partial least square diterapkan untuk menguji hubungan antara purchase intention, brand experience, brand awareness, brand visibility dan brand reputation. Hasil penelitian ini menunjukkan bahwa dari empat hipotesis yang dikembangkan terdapat satu hipotesis yang ditolak, yaitu untuk pengaruh antara variabel brand awareness terhadap variabel purchase intention tidak berpengaruh secara signifikan. Sedangkan untuk variabel brand experience, brand visibility dan brand reputation berpengaruh signifikan terhadap purchase intention. Melalui temuan dari penelitian ini, diharapkan dapat memberikan tambahan informasi bagi berbagai pihak seperti toko konvensional maupun toko online serta perusahaan yang menyediakan produk smartphone untuk memperhatikan faktor-faktor yang mendorong minat beli konsumen sehingga konsumen memperoleh kenyamanan dan kepercayaan pada produk tersebut.
\end{abstract}

Kata Kunci:

Brand Experience; Brand Awareness; Brand Visibility; Brand Reputation; Purchase Intention. 


\begin{abstract}
Online shopping behavior and online learning using electronic devices, such as smartphones, are currently an interesting phenomenon in Indonesia. The use of smartphones which continues to increase sharply is certainly inseparable from the role of the brand management of the smartphone product. This study aimed to analyze the role of brand experience, brand awareness, brand visibility, and brand reputation in improving purchase intention in generation $Z$. This study used a research design with a quantitative approach. The data were collected through documentation and online questionnaires. This study used a sample of 180 respondents with the determination of the sample size using purposive sampling formula. Partial least squares were applied to examine the relationship between purchase intention, brand experience, brand awareness, brand visibility, and brand reputation. The results of this study showed that of the four hypotheses developed, one hypothesis was rejected, in which the effect of the brand awareness variable on the purchase intention variable did not have a significant effect. Meanwhile, brand experience, brand visibility, and brand reputation had a significant effect on purchase intention. Based on the findings of this study, it is expected that it can provide additional information for various parties such as traditional stores and online stores, also companies that provide smartphone products to consider the factors that encourage consumer purchase intention so that they gain comfort and trust in these products.
\end{abstract}

Keywords:

Brand Experience; Brand Awareness; Brand Visibility; Brand Reputation; Purchase Intention. 


\section{PENDAHULUAN}

Belanja online dan bermain game dengan menggunakan smartphone saat ini menjadi fenomena yang menarik di Indonesia. Survei data menunjukkan perkembangan yang sangat pesat terjadi dari segi konsumen online (Hadita et al., 2020). Dengan banyaknya jumlah konsumen yang karantina dirumah akibat kebijakan pemerintah dalam mengantisipasi penyebaran virus Covid-19 tentunya penggunaan smartphone akan semakin bertambah, namun keadaan tersebut kontradiksi dengan tingkat penjualan beberapa merek produk smartphone di Indonesia seperti yang terlihat pada gambar 1 di bawah ini.

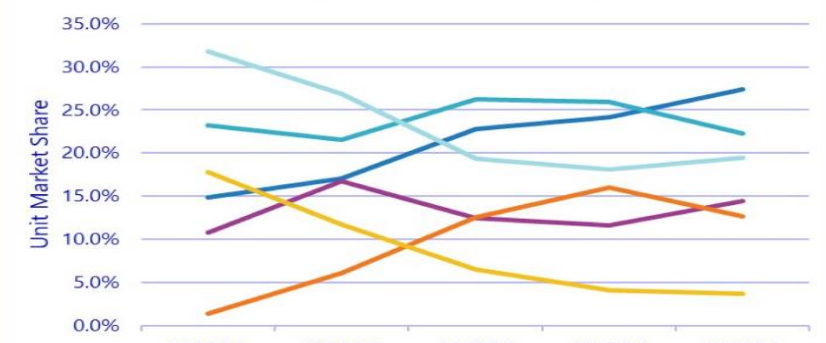

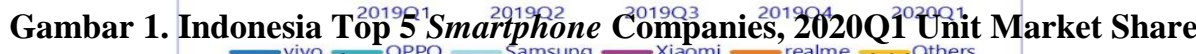
Sumber: International Data Corporation, $2020^{\text {thers }}$

Berdasarkan gambar 1 di atas terlihat pada kuartal pertama tahun 2020, pasar ponsel pintar Indonesia mengirimkan 7,5 juta unit, turun -7,3\% jika dibandingkan year over year (YoY) dan -24,1\% quarter over quarter (QoQ), mencapai rekor terendah baru dalam dua tahun terakhir. Menurut ke IDC Quarterly Mobile Phone Tracker, penurunan ini disebabkan oleh dampak pandemi Covid-19 dalam beberapa minggu terakhir pada kuartal yang mempengaruhi pasar lebih lanjut (Febrian, 2020). Sebagian merek bisa menjaga bisnisnya sebab terdapatnya topangan dari sebagian cadangan unsur yang karakternya relatif nyaman pada kuartal awal dan dibantu dengan sarana pembuatan yang maksimal akibatnya terbentuknya ketidakstabilan pemasaran hanya terjalin pada bulan maret. Lebih lanjut, pada bulan maret sudah nampak isyarat terbentuknya perlambatan market share untuk produk ponsel pintar disebabkan terdapatnya peraturan dari pemerintah terkait pembatasan sosial berskala besar (Febrian, 2020).

Fungsi smartphone tidak hanya sebagai alat komunikasi, melainkan saat ini telah menjadi kebutuhan pokok bagi masyarakat. Eksistensi sebuah produk smartphone sangat tergantung pada pengelolaan brand management yang dikelola oleh perusahaan maupun industri (Ramaseshan \& Stein, 2014). Bagi konsumen, fungsi merek secara psikologis dan sosial lebih menonjol kepada eksistensi diri, pembeda antar konsumen di dalam lingkungan sosial, penanda nilai eksklusivitas personal, mewakili karakter penggunanya bahkan sekaligus dapat menjadi penentu kesan strata sosial dalam lingkungan seharian (Kusuma et al., 2020).

Manifestasi dalam bentuk ikatan yang emosional antara pelanggan dengan merek produk merupakan bagian dari upaya menjalankan proses branding (Razak et al., 2020). Opsi merek konsumen ialah strategi bernilai mengarah uraian sikap preferensi konsumen akibatnya dibutuhkan atensi besar oleh industri pada aspek tersebut. Tetapi, riset mengenai preferensi merek spesialnya pada produk 
ponsel pintar terbatas pada penjualan konvensional yang berpusat pada ciri fungsional dalam mengoptimalkan manfaat (Sudirman et al., 2020). Dilihat dari jenis konsumen, banyak pengguna internet di Indonesia didominasi oleh rentang usia 10 hingga 24 tahun yang merupakan generasi $\mathrm{Z}$ dan generasi Y (APJII, 2018).

Secara umum generasi $\mathrm{Z}$ memiliki pemahaman yang berbeda dari generasi sebelumnya dalam mengakses informasi yang berhubungan dengan brand, khususnya dalam menggunakan perangkat teknologi informasi (Sata, 2013). Dilihat dari prospek yang besar dalam lingkungan bisnis, maka penting untuk menjadikan generasi $\mathrm{Z}$ sebagai responden dalam penelitian ini dikarenakan pada tahun 2030 diprediksi indonesia akan mengalami bonus demografi yang tentunya dapat memberikan gambaran khusus bagi produsen smartphone untuk menciptakan produk smartphone yang sesuai dengan kriteria mereka pada masa yang akan datang (Wong \& Mo, 2019).

Penelitian Sanjaya et al., (2020), menyampaikan ada kontribusi yang signifikan dari brand experience terhadap purchase intention. Sedangkan hasil riset Murtingsih et al., (2019), menyatakan brand experience tidak memiliki pengaruh yang signifikan terhadap purchase intention. Selanjutnya hasil studi Eliasari \& Sukaatmadja (2017), menyampaikan ada kontribusi yang signifikan dari brand awareness terhadap purchase intention. Temuan ini bertentangan dengan hasil riset Fenetta \& Keni (2020), yang menyatakan tidak ada pengaruh yang signifikan yang diberikan brand awareness terhadap purchase intention.

Lebih lanjut hasil studi Vianna et al., (2016), menyampaikan ada kontribusi yang signifikan dari brand visibility terhadap purchase intention. Disisi lain, hasil penelitian ini tidak sejalan dengan penelitian Larasari et al., (2018), yang menyatakan tidak ada pengaruh yang signifikan antara brand visibility terhadap purchase intention. Kemudian hasil riset yang dilakukan Udayana (2015), menyampaikan ada kontribusi yang signifikan dari brand reputation terhadap purchase intention. Sedangkan penelitian yang dilakukan Agmeka et al., (2019), menemukan hasil yang berbeda dengan temuan brand reputation tidak memiliki pengaruh yang signifikan terhadap purchase intention.

Research gap dalam penelitian ini terletak pada hasil yang berbeda dari referensi terdahulu mengenai pengaruh brand experience, brand awareness, brand visibility dan brand reputation terhadap purchase intention, sehingga membuka celah bagi peneliti untuk meneliti lebih lanjut dengan menggunakan pengukuran indikator variabel independen yang berbeda dari penelitian sebelumnya. Urgensi dari penelitian ini adalah untuk menjembatani penelitian terdahulu yang mengkaji tentang aspek brand experience, brand awareness, brand visibility dan brand reputation terhadap purchase intention. Penelitian ini memiliki tujuan untuk mengetahui kontribusi dari brand experience, brand awareness, brand visibility dan brand reputation terhadap purchase intention di kalangan generasi $\mathrm{Z}$ pada produk smartphone.

\section{Brand Management}


Merek merupakan simbol yang menjadi penanda sekaligus menjadi pembeda antara satu produk dengan produk lainnya. Secara kasat mata, merek juga memberikan referensi bagi konsumen untuk menandai apakah suatu produk berkelas atau tidak sama sekali (Kusuma et al., 2020). Kesuksesan yang ditampilkan sebuah merek akan terlihat ketika peran merek yang telah dibangunnya berdasarkan pengalaman yang telah berlangsung beberapa dekade dapat terus eksis sampai sekarang. Pengelolaan secara maksimal terhadap brand merupakan salah satu langkah strategis perusahaan agar memperoleh keuntungan yang maksimal dalam jangka panjang (Veloutsou \& Guzman, 2017). Perencanaan manajemen merek yag sukses akan berimplikasi pada ketahanan merek selama beberapa dekade meskipun diterpa dengan namanya disrupsi. Inilah salah satu peran yang paling krusial bagi manajemen perusahaan untuk dapat meningkatkan pengelolaan manajemen merek dengan optimal. Tujuan akhir daripada brand management adalah peningkatan loyalitas dan juga repeat buying suatu produk sebagai wujud dari brand performance (Ilyas et al., 2020).

\section{Purchase Intention}

Niat pembelian berasal dari pemikiran kognitif konsumen yang diharapkan untuk membeli produk pada merek tertentu (Su \& Huang, 2011). Purchase intention merupakan keinginan konsumen untuk membeli karena konsumen membutuhkan produk atau jasa tersebut yang menimbulkan sikap dan persepsi (Madahi \& Sukati, 2012). Suatu keadaan yang mencerminkan intensi seseorang untuk melakukan pembelian suatu produk ataupun jasa dari perusahaan maupun industri dapat terjadi karena adanya keinginan serta dorongan kuat yang timbul dari pikiran (Wilson et al., 2019). Representatif dari sikap atau keinginan untuk membeli suatu produk di masa depan merupakan indikasi yang mengarah pada tindakan untuk melakukan niat pembelian secara berulang-ulang (Wu et al., 2011).

\section{Brand Experience}

Pengalaman merek merupakan dampak dari keseluruhan yang dimiliki merek terhadap pengguna berdasarkan kombinasi elemen pemasaran yang disatukan berurutan untuk mengkomunikasikan merek (Shamim \& Mohsin Butt, 2013). Manifestasi dari pengalaman merek dianggap sebagai perwujudan indrawi merek yang terhubung dengan panca indera konsumen (Hultén, 2011). Indikator pengalaman merek menurut (Brakus et al., 2009), terdiri dari sensorik, afeksi, perilaku, intelektual. Pengalaman merek dirancang untuk menimbulkan rangsangan dari komunikasi desain merek dalam bentuk sensasi, perasaan, kognisi, dan perilaku tanggapan yang ditimbulkan oleh rangsangan dari komunikasi desain merek dan lingkungan (Sanjaya et al., 2020).

\section{Brand Awareness}

Kesadaran merek umumnya dalam pemasaran diartikan sebagai dorongan bagi konsumen untuk menyadari sesuatu yang berhubungan dengan bisnis. Pemahaman merek dipakai buat mengukur kemahiran konsumen potensial yang tidak cuma mengidentifikasi penilaian merek, namun pula mengaitkannya dengan produk ataupun layanan industri tertentu (Wilson, 2020). Ketika konsumen menyadari produk yang ditawarkan suatu perusahaan, konsumen akan lebih cenderung langsung pergi 
ke perusahaan itu jika mereka membutuhkan produk itu (Ilyas et al., 2020). Representatif dari kekuatan sebuah merek akan terlihat ketika kesadaran merek dibangun dapat bekerja dengan optimal yang tercermin dari kemampuan konsumen untuk mengingat atau mengenali merek dalam kondisi berbeda (Martins et al., 2019).

\section{Brand Visibility}

Visibilitas merek merupakan faktor kunci tambahan di mana identitas suatu merek dihubungkan dengan citra merek maupun preferensi merek (Vianna et al., 2016). Visibilitas merek di era digital atau visibilitas merek online merupakan hasil dari membangun kepercayaan dengan audiens yang menjadi target perusahaan Adamson et al., (2017). Visibilitas merek online dimulai dengan memasukkan konten berkualitas ke situs web perusahaan (Dutot \& Bergeron, 2016). Di mana kualitas konten merupakan ukuran tingkat kepercayaan audiens atas manfaat informasi yang didapatkan sesuai dengan yang diharapkan dari suatu situs web (Kusuma et al., 2020). Kondisi sebuah merek yang dapat diamati pada suatu produk barang ataupun jasa maka disebut dengan visibilitas merek. Secara khusus visibilitas merek memiliki keterkaitan dengan kegiatan promosi yang dilakukan perusahaan maupun organisasi bisnis (Razak et al., 2020).

\section{Brand Reputation}

Brand Reputation sangat dibutuhkan perusahaan sebagai sarana menaikkan kepercayaan pelanggan. Reputasi merek merupakan penghargaan yang diraih perusahaan karena kelebihan atau keunggulan yang dimiliki perusahaan tersebut (Han et al., 2015). Brand reputation dapat dieksplorasi secara komprehensif melalui sentuhan kualitas dan kinerja produk dan tidak hanya dapat dilakukan pada bauran pemasaran seperti advertising dan public relation saja (Efrat \& Asseraf, 2019). Reputasi merek tercermin tidak hanya melalui pengalaman tetapi juga diukur melalui kemampuan hubungan pemasaran perusahaan sebagai strategi untuk memperkenalkan produk baru atau menjaga keberlangsungan produk yang sudah ada (Razak et al., 2020).

Berdasarkan uraian di atas, maka konsep kerangka pemikiran dalam penelitian ini dapat dijelaskan pada gambar 1 berikut ini:

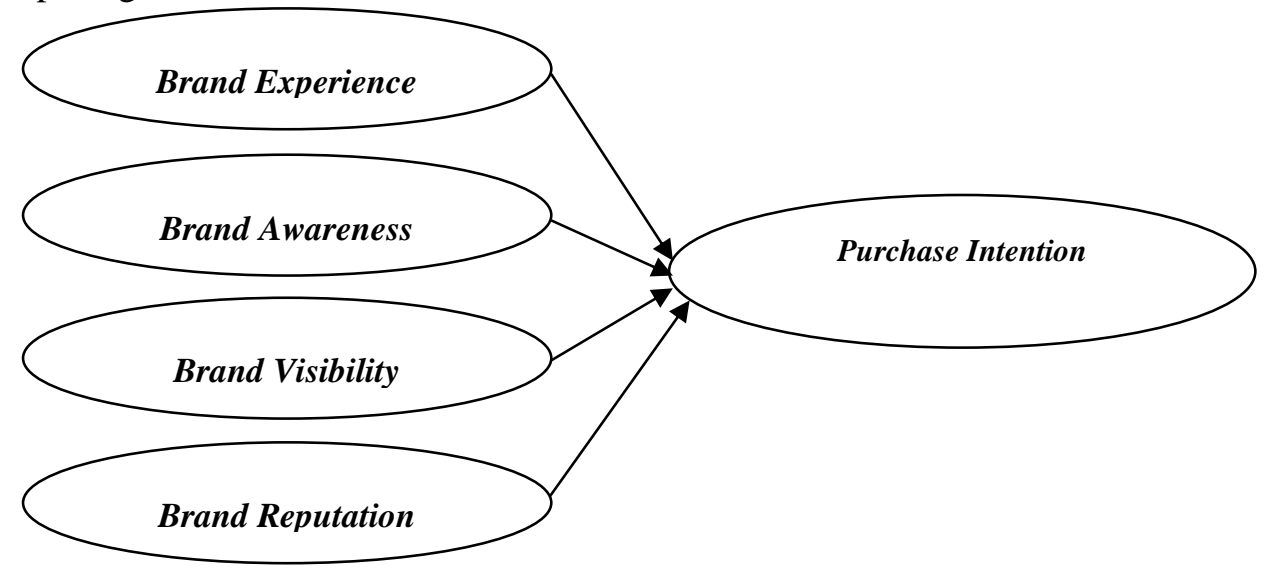


Berdasarkan latar belakang masalah dan kerangka pemikiran pada gambar 2 yang telah disampaikan sebelumnya, maka hipotesis yang dibangun dalam penelitian ini adalah sebagai berikut:

Hipotesis 1: brand experience berpengaruh terhadap purchase intention

Hipotesis 2: brand awareness berpengaruh terhadap purchase intention

Hipotesis 3: brand visibility berpengaruh terhadap purchase intention

Hipotesis 4: brand reputation berpengaruh terhadap purchase intention

\section{METODE RISET}

Penelitian ini menggunakan metode dengan pendekatan kuantitatif yang dinilai dengan analisis PLS-SEM dalam proses dua tahap. Pertama, data penelitian yang dianalisis validitas dan reliabilitasnya dengan menggunakan pengujian cronbach's alpha, composite reliability, outer loading dan average variance extracted. Kemudian, melakukan analisis Analisis Faktor Konfirmatori untuk memeriksa kecocokan model dan keandalan model serta membahas hipotesis melalui Structural Equation Model (SEM) berbasis varians (Hair, 2014).

Untuk penentuan ukuran sampel digunakan memakai rumus sampling purposive. Sampling purposive merupakan pertimbangan tertentu dari teknik penentuan sampel. Karakteristik responden yang dibutuhkan dalam penelitian ini antara lain adalah pengguna aktif smartphone dan telah menggunakan lebih dari satu merek smartphone. Jumlah sampel dalam penelitian ini sebanyak 180 responden. Instrumen yang dipakai untuk penelitian ini menggunakan kuesioner online. Skala dalam penelitian ini yaitu dengan skala likert (1) yang menyatakan "sangat tidak setuju hingga" (5) "sangat setuju".

Pengukuran variabel dependen, yaitu purchase intention diukur dengan menggunakan penelitian terdahulu (Putra et al., 2018), yang terdiri dari 4 item. Kemudian untuk varibael independen pertama, yaitu brand experience diukur dengan menggunakan penelitian terdahulu (Ramaseshan \& Stein, 2014), yang terdiri dari 4 item, independen kedua, yaitu brand awareness diukur dengan menggunakan penelitian terdahulu (Han et al., 2015), yang terdiri dari 3 item, independen ketiga, yaitu brand visibility diukur dengan menggunakan penelitian terdahulu (Razak et al., 2020), yang telah dimodifikasi menjadi 5 item dan yang independen keempat, yaitu brand reputation diukur dengan menggunakan penelitian terdahulu (Veloutsou \& Moutinho, 2009) yang terdiri dari 3 item..

\section{HASIL PENELITIAN DAN PEMBAHASAN}

\section{Karakteristik Responden}

Penyebaran kuesioner dilakukan secara online melalui media sosial WhatsApp dan Telegram. Media sosial dipilih karena target responden banyak yang aktif menggunakan sosial media dalam kehidupan sehari hari mereka. Dari 212 respons yang diterima hanya 180 data $(84,90 \%)$ yang dinilai 
valid untuk penelitian. Karakteristik responden dalam penelitian ini secara jelas akan diuraikan pada tabel 1 berikut ini.

Tabel 1. Profil Umum Responden

\begin{tabular}{|c|c|c|c|}
\hline Kategori & Detail & Jumlah & Persentase \\
\hline \multirow{3}{*}{ Jenis Kelamin } & Pria & 84 & $46,67 \%$ \\
\hline & Wanita & 96 & $53,33 \%$ \\
\hline & 14-16 tahun & 12 & $6,67 \%$ \\
\hline \multirow{2}{*}{ Usia } & 17-19 tahun & 43 & $23,89 \%$ \\
\hline & 20-22 tahun & 55 & $30,56 \%$ \\
\hline \multirow{6}{*}{ Pendidikan } & 23-25 tahun & 70 & $38,89 \%$ \\
\hline & SMA & 88 & $48,89 \%$ \\
\hline & D1 sampai D3 & 37 & $20,56 \%$ \\
\hline & $\mathrm{S} 1$ & 51 & $28,33 \%$ \\
\hline & S2 & 4 & $2,22 \%$ \\
\hline & Pelajar & 19 & $10,56 \%$ \\
\hline \multirow{5}{*}{ Pekerjaan } & Mahasiswa & 30 & $16,67 \%$ \\
\hline & Karyawan & 83 & $46,11 \%$ \\
\hline & Wirausaha & 32 & $17,78 \%$ \\
\hline & Pegawai Negeri & 9 & $5,00 \%$ \\
\hline & Lainnya & 7 & $3,89 \%$ \\
\hline \multirow{4}{*}{ Pendapatan } & $<\operatorname{Rp} 1.000 .000$ & 19 & $10,56 \%$ \\
\hline & Rp 1.000.000 - Rp 5.000.000 & 51 & $28,33 \%$ \\
\hline & Rp 5.000.000 - Rp 9.000.000 & 86 & $47,78 \%$ \\
\hline & $>\operatorname{Rp} 10.000 .000$ & 24 & $13,33 \%$ \\
\hline
\end{tabular}

\section{Pengukuran Outler Model}

Hasil data yang diperoleh dari kuesioner penelitian diolah menggunakan aplikasi SmartPLS versi 3.2.9. Dalam pengukuran outer model, pengujian yang dilakukan adalah uji validitas dan uji relibilitas. Pengujian validitas konvergen yang ditentukan oleh loading factor dan AVE dengan syarat loading factor diatas 0,7 dan nilai AVE sebesar 0,5 (Hair, 2014). Pengujian reliabilitas model menurut (Hair, 2014) dilihat dari nilai cronbanch's alpha dan composite reliability (CR) yang memiliki nilai lebih besar dari 0,7 . Berikut ini akan ditampilkan penjelasan mengenai pengukuran outler model yang disajikan pada tabel 2.

Pada pengujian uji validitas yang disajikan pada tabel 2 di atas, diketahui nilai masing-masing loading factor dan AVE pada indikator brand experience, brand awareness, brand visibility, brand reputation dan purchase intention berada pada di atas 0,7 untuk loading factor dan di atas 0,5 untuk AVE. Selanjutnya nilai untuk masing-masing reliabilitas diatas diperoleh nilai composite reliability untuk masing-masing variabel penelitian adalah di atas 0,7 yang dapat dijelaskan sebagai berikut: brand experience memperoleh 0,983 , brand awareness memperoleh 0,899, brand visibility memperoleh 0,944 , brand reputation memperoleh 0,964 dan purchase intention memperoleh 0,852 . Selanjutnya untuk nilai cronbach's alpha diperoleh nilai untuk masing-masing variabel di atas 0,7 hal ini menunjukkan bahwa semua variabel penelitian mempunyai nilai reliabilitas yang baik. Dengan nilai 
yang baik ini maka dapat digunakan sebagai gambaran dari kondisi keterkaitan antar variabel juga baik sehingga dapat dilakukan uji lebih lanjut

Tabel 2. Hasil Pengukuran Outler Model

\begin{tabular}{|c|c|c|c|c|}
\hline Construct/item & $\begin{array}{c}\text { Outler } \\
\text { Loadings }\end{array}$ & $\begin{array}{l}\text { Cronbach's } \\
\text { alpha }\end{array}$ & $\mathbf{C R}$ & AVE \\
\hline Brand Experience & & 0,976 & 0,983 & 0,749 \\
\hline Sensory & 0,978 & & & \\
\hline Affective & 0,915 & & & \\
\hline Behavioural & 0,989 & & & \\
\hline Intellectual & 0,982 & & & \\
\hline Brand Awareness & & 0,848 & 0,899 & 0,935 \\
\hline Pengetahuan setiap merek smartphone & 0,909 & & & \\
\hline Pengenalan dengan setiap merek smartphone & 0,802 & & & \\
\hline $\begin{array}{l}\text { Kemampuan mengenali merek ini di antara merek } \\
\text { smartphone lainnya }\end{array}$ & 0,883 & & & \\
\hline Brand Visibility & & 0,925 & 0,944 & 0,774 \\
\hline $\begin{array}{l}\text { Merek smartphone memiliki metode periklanan yang } \\
\text { cukup jelas }\end{array}$ & 0,917 & & & \\
\hline $\begin{array}{l}\text { Penentuan posisi dan penargetan saluran promosi cukup } \\
\text { masif }\end{array}$ & 0,956 & & & \\
\hline $\begin{array}{l}\text { Penggunaan saluran periklanan tidak hanya offline tetapi } \\
\text { juga online }\end{array}$ & 0,738 & & & \\
\hline $\begin{array}{l}\text { Produk adalah pelopor dan keahlian dalam pengembangan } \\
\text { produk lanjutan }\end{array}$ & 0,936 & & & \\
\hline $\begin{array}{l}\text { Produk selalu melakukan evaluasi terhadap produk yang } \\
\text { mereka buat }\end{array}$ & 0,833 & & & \\
\hline Brand Reputation & & 0,943 & 0,964 & 0,898 \\
\hline Merek smartphone ini dapat dipercaya & 0,945 & & & \\
\hline Merek smartphone ini memiliki reputasi baik & 0,934 & & & \\
\hline Merek smartphone ini membuat klaim yang jujur & 0,964 & & & \\
\hline Purchase Intention & & 0,767 & 0,852 & 0,590 \\
\hline Brand dapat memberikan pengaruh bagi calon konsumen & 0,753 & & & \\
\hline Kualitas produk yang ditawarkan sesuai & 0,711 & & & \\
\hline Harga yang kompetitif & 0,800 & & & \\
\hline Keinginan untuk membeli akibat informasi yang menarik & 0,804 & & & \\
\hline
\end{tabular}
Sumber: Olahan Data (2020)

\section{Pengukuran Inner Model}

Pengukuran inner model dilakukan dengan cara bootstrapping data hasil penelitian menggunakan SmartPLS 3.2.9. Ada dua hasil yang diperoleh dari bootstrapping, yang pertama adalah signifikansi dari dua variabel terkait, dan juga $R$-square penelitian. Nilai dari $R$-square adalah nilai yang menunjukan kemampuan variabel- variabel eksogen membangun variabel endogen. Menurut (Chin et al., 2008), ada tiga kategori dari nilai $R$-square, jika nilai $R$-square adalah 0,19 hubungan antara variabel eksogen membentuk variabel endogen adalah lemah, jika bernilai 0,33 artinya hubungannya moderat dan jika nilainya adalah 0,67 pertanda bahwa hubungannya kuat. Sedangkan (Sarwono, 2016), menyatakan bahwa jika nilai R- square nya lebih dari 0,67 maka hubungan antar endogen dan eksogennya adalah sangat kuat.

Tabel 3. Hasil Perhitungan nilai R-Square

\begin{tabular}{ccc}
\hline Keterangan & $R$ Square & $R$ Square Adjusted \\
\hline Purchase Intention & 0.655 & 0.645 \\
\hline \multicolumn{3}{c}{ Sumber: Olahan Data (2020) }
\end{tabular}


Dilihat dari nilai $R$-square tiap tiap variabel endogen, diperoleh nilai 0.655 yang nilainya berkisar antara 0,33-0,67 ini menunjukan bahwa secara keseluruhan kemampuan variabel variabel eksogen menjelaskan endogen adalah moderat. Selanjutnya untuk membuktikan pengujian hipotesis, maka dilakukan uji signifikansi yang digunakan untuk mengetahui hubungan antara variabel eksogen terhadap variabel endogennya. Kriteria signifikannya adalah dilihat dari nilai p-value. Dengan tingkat signifikansi 5\%, jika nilai p-value antara variabel eksogen dan endogen besarnya kurang dari 0,05 artinya variabel eksogen berpengaruh secara signifikan terhadap variabel endogen, sebaliknya jika nilainya lebih besar dari 0,05 artinya variabel eksogen tidak berpengaruh secara signifikan dalam membangun variabel endogennya.

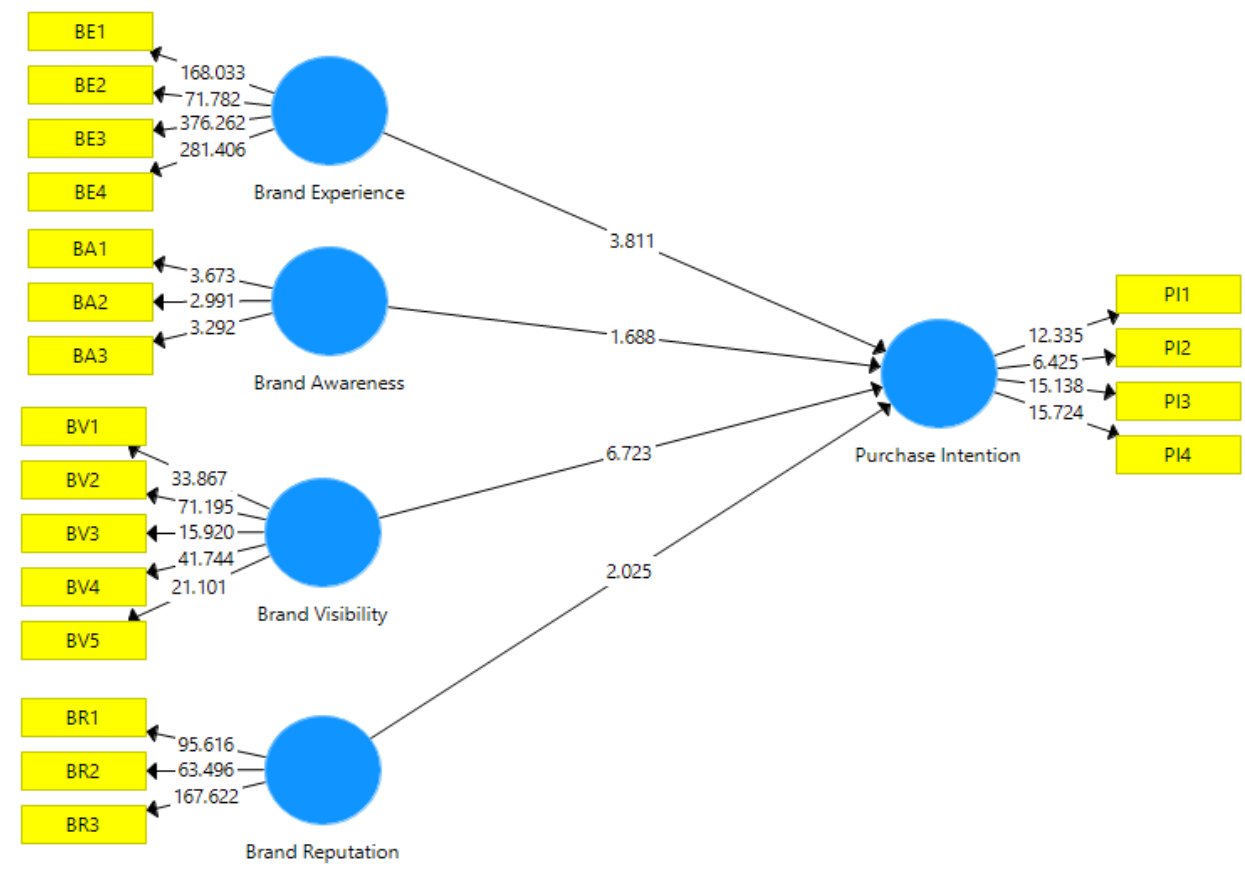

Gambar 3. Tampilan Inner Model

Sumber: Olahan Data (2020)

Tabel 4. Hasil Uji Path Coefficients

\begin{tabular}{|c|c|c|c|c|}
\hline Path Antar Variabel & Koefisien & thitung & P-Value & Kesimpulan \\
\hline $\begin{array}{l}\text { Brand Experience >> Purchase } \\
\text { Intention }\end{array}$ & 0.254 & 3.811 & 0.000 & Signifikan \\
\hline $\begin{array}{l}\text { Brand Awareness }>>\text { Purchase } \\
\text { Intention }\end{array}$ & 0.131 & 1.688 & 0.092 & Tidak Signifikan \\
\hline Brand Visibility $\gg$ Purchase Intention & 0.564 & 2.025 & 0.043 & Signifikan \\
\hline $\begin{array}{l}\text { Brand Reputation } \gg \text { Purchase } \\
\text { Intention }\end{array}$ & 0.125 & 6.723 & 0.000 & Signifikan \\
\hline
\end{tabular}

Sumber: Olahan Data (2020)

Berdasarkan hasil olahan data yang disajikan pada tabel 4 di atas, uji signifikansi hubungan langsung antara variabel eksogen dan endogen dapat dikatakan secara keseluruhan variabel eksogen berpengaruh secara signifikan terhadap variabel endogennya, meskipun ada satu variabel eksogen yang tidak berpengaruh terhadap variabel endogennya. Dari 4 hipotesis yang dikembangkan terdapat 1 hipotesis yang ditolak, yaitu untuk pengaruh antara variabel brand awareness terhadap variabel 
purchase intention tidak berpengaruh secara signifikan. Sedangkan untuk variabel brand experience, brand visibility dan brand reputation berpengaruh signifikan terhadap purchase intention.

\section{Pembahasan}

\section{Pengaruh Brand Experience Terhadap Purchase Intention}

Hasil penelitian menunjukkan bahwa brand experience berpengaruh positif dan signifikan terhadap purchase intention. Perihal ini berarti konsumen yang mempunyai pengalaman dalam memakai merek produk yang bagus akan berimplikasi pada hasrat beli yang besar buat membeli sesuatu produk (Aulianda et al., 2020). Konseptualisasi suatu merek yang mengarah pada kesadaran, rancangan serta bukti diri merek ialah wujud interprestasi mengenai suatu merek yang timbul pada saat terdapatnya ransangan yang merefleksikan totalitas merek itu sendiri (Sudirman et al., 2020). Hasil penelitian ini sejalan dengan hasil penelitian Ebrahim et al., (2016) dan Setyawan \& Adiwijaya (2018), yang menyebutkan naiknya minat beli dipengaruhi oleh brand experience yang dialami seorang konsumen.

\section{Pengaruh Brand Awareness Terhadap Purchase Intention}

Hasil penelitian menunjukkan bahwa brand awareness berpengaruh positif namun tidak signifikan terhadap purchase intention. Hasil penelitian ini sejalan Maulidi \& Yuliati, (2017), yang menyatakan konsumen yang memiliki pengetahuan dan kesadaran dalam menggunakan merek produk tertentu, ternyata belum cukup kuat mendorong minat belinya. Situasi ini melukiskan jika atensi beli seseorang bisa dibangun lewat pengalaman atau keyakinan yang dialami konsumen pada disaat membeli ataupun mengkonsumsi sebagian produk yang mengarah pada merek tertentu (Iswandi \& Ester, 2020). Namun penelitian ini tidak sejalan dengan penelitian yang disampaikan Hakim (2020) dan Wilson (2020), yang menyatakan kekuatan sebuah merek yang dibangun melalui kesadaran merek mampu mendorong seseorang untuk melakukan pembelian suatu produk.

\section{Pengaruh Brand Visibility Terhadap Purchase Intention}

Hasil penelitian menunjukkan bahwa brand visibility berpengaruh positif dan signifikan terhadap purchase intention. Merek dengan brand visibility yang baik tingkat kualitas tertentu dapat memberi sinyal pada pembeli untuk melihat produk serta layanan dari brand (Sudarso et al., 2019). Hasil ini sejalan dengan penelitian (Vianna et al., 2016), yang menyampaikan peningkatan purchase intention didorong dengan penataan brand visibility yang baik. Salah satu tujuan kampanye merek adalah menciptakan visibilitas yang lebih besar ke merek tertentu, memahami bahwa tindakan ini dapat menghasilkan peningkatan penjualan melalui niat beli yang tinggi (Vianna et al., 2016).

\section{Pengaruh Brand Reputation Terhadap Purchase Intention}

Hasil penelitian menunjukkan bahwa brand reputation berpengaruh positif dan signifikan terhadap purchase intention. Hasil ini sesuai dengan penelitian yang disampaikan oleh Widjajanta et al., (2020), yang menyatakan ada pengaruh yang signifikan antara brand reputation terhadap purchase intention. Kemampuan perusahaan dalam menumbuhkan kepercayaan atas merek produknya melalui 
reputasi mereknya akan berimplikasi pada peningkatan pembelian produk dalam jangka panjang (Chu et al., 2005). Penelitian Kim \& Wha (2020), menyampaikan pengaruh reputasi merek harus dipertimbangkan saat membangun sebuah strategi merek yang keberlanjutan. Ketika konsumen merasakan reputasi merek suatu produk rendah, maka tingkat keberlanjutan yang dipersepsikan secara langsung mempengaruhi niat beli.

\section{KESIMPULAN DAN SARAN}

\section{Kesimpulan}

Dari hasil pengujian hipotesis yang dilakukan, maka kesimpulan dalam penelitian ini adalah sebagai berikut:

1. Hasil pengujian variabel brand experience menunjukkan pengaruh positif dan signifikan terhadap purchase intention.

2. Hasil pengujian variabel brand awareness menunjukkan pengaruh positif namun tidak signifikan terhadap purchase intention.

3. Hasil pengujian variabel brand visibility menunjukkan pengaruh positif dan signifikan terhadap purchase intention.

4. Hasil pengujian variabel brand reputation menunjukkan pengaruh positif dan signifikan terhadap purchase intention.

\section{Implikasi Penelitian}

Secara praktis, terdapat beberapa implikasi penting dalam penelitian ini. Pertama, brand experience, brand visibility, brand reputation merupakan faktor penting dalam mempengaruhi purchase intention produk smartphone. Selanjutnya hasil temuan menyatakan brand awareness tidak memiliki pengaruh yang signifikan terhadap purchase intention, sehingga diperlukan perhatian khusus pada aspek ini sebagai stimulus untuk mendorong purchase intention. Kemudian sebagai tambahan informasi bagi berbagai pihak seperti toko konvensional maupun toko online serta perusahaan yang menyediakan produk smartphone agar memperhatikan faktor-faktor di atas sehingga konsumen memperoleh kenyamanan dan kepercayaan pada produk tersebut. Kedua, pihak penyedia perlu memastikan bahwa toko konvensional maupun toko online yang memberikan harga murah dapat menjamin produk yang mereka jual memiliki kualitas yang baik. Sehingga, konsumen mendapatkan produk yang berkualitas walaupun dengan harga yang yang dibandrol lebih mahal.

\section{Keterbatasan dan Saran}

Penelitian ini memiliki keterbatasan dan saran yang kemungkinan dapat mempengaruhi hasil penelitian selanjutnya, yaitu:

1. Penelitian ini hanya terbatas pada responden generasi $Z$ yang berjumlah 180 orang responden di Kota Pematangsiantar sehingga dirasa masih terlalu kecil dibandingkan dengan jumlah generasi $\mathrm{Z}$ yang menggunakan smartphone di Indonesia. Maka dari itu, penelitian ini belum 
dapat menggambarkan secara jelas perbedaan dari penggunaan smartphone. Untuk penelitian selanjutnya disarankan untuk menambah jumlah sampel dan memilih lokasi atau tempat penelitian dengan scope yang lebih luas agar penelitian dapat dilakukan generalisasi.

2. Dalam penelitian ini, peneliti hanya meneliti 4 variabel independen yaitu brand experience, brand awareness, brand visibility, brand reputation sehingga tidak dapat mencakup dan mengetahui seluruh variabel yang memengaruhi perilaku pembelian smartphone pada generasi Z. Penelitian selanjutnya sebaiknya perlu menambah beberapa variabel dari aspek brand management, seperti brand attitude, brand love, brand image, brand emotional, dan lain-lain. 


\section{DAFTAR PUSTAKA}

Adamson, M. A., Chen, H., Kackley, R., dan Micheal, A. (2017). For the love of the game: game-versus lecture-based learning with Generation z patients. Journal of Psychosocial Nursing and Mental Health Services, 56(2), 29-36

Agmeka, F., Wathoni, R. N., dan Santoso, A. S. (2019). The Influence Of Discount Framing Towards Brand Reputation And Brand Image On Purchase Intention And Actual Behaviour In E$\begin{array}{llll}\text { Commerce. } & \text { Procedia } & \text { Computer } & \text { Science, }\end{array}$ https://doi.org/10.1016/j.procs.2019.11.192

APJII. (2018). Hasil Survei Penetrasi dan Perilaku Pengguna Internet Indonesia 2018. https://www.apjii.or.id/content/read/39/410/Hasil-Survei-Penetrasi-dan-Perilaku-PenggunaInternet-Indonesia-2018

Aulianda, M., Hudayah, S., dan Rahmawati. (2020). Pengaruh Brand Experience Dan Brand Image Terhadap Willingness To Pay A Price Premium Dengan Brand Love Sebagai Variabel Intervening ( Studi Pada Pemilik Mobil Merek Honda HRV di Samarinda ) Mega Aulianda. Jurnal Riset Entreprenurship, 3(2), 71-79.

Brakus, J. J., Schmitt, B. H., dan Zarantonello, L. (2009). Brand Experience: What Is It? How Is It Measured? Does It Affect Loyalty? Journal of Marketing, 73(3), 52-68. https://doi.org/10.1509/jmkg.73.3.52

Chin, W. W., Peterson, R. A., dan Brown, S. P. (2008). Structural Equation Modeling In Marketing: Some Practical Reminders Structural Equation Modeling In Marketing: Some Practical Reminders. Journal of Marketing Theory and Practice ISSN:, 16(4), 287-298. https://doi.org/10.2753/MTP1069-6679160402

Chu, W., Choi, B., dan Song, M. R. (2005). The Role Of On-Line Retailer Brand And Infomediary Reputation In Increasing Consumer Purchase Intention. International Journal of Electronic Commerce, 9(3), 115-127. https://doi.org/10.1080/10864415.2005.11044336

Dutot, V. dan Bergeron, F. (2016). From Strategic Orientation To Social Media Orientation: Improving Smes' Performance On Social Medi. Journal of Small Business and Enterprise Development, 23(4), 1165-1190. https://doi.org/https://doi.org/10.1108/JSBED-11-2015-0160 
Ebrahim, R., Ghoneim, A., Irani, Z., dan Fan, Y. (2016). A brand preference and repurchase intention model: the role of consumer experience. Journal of Marketing Management, 32(13-14), 12301259. https://doi.org/10.1080/0267257X.2016.1150322

Efrat, K., dan Asseraf, Y. (2019). A shift in perspective? The role of emotional branding in shaping born globals' performance. International Business Review, 28(6), 101589. https://doi.org/10.1016/j.ibusrev.2019.101589

Eliasari, P., dan Sukaatmadja, I. (2017). Pengaruh Brand Awareness Terhadap Purchase-Intention Dimediasi Oleh Perceived-Quality Dan-Brand-Loyalty. E-Jurnal Manajemen Universitas Udayana, 6(12), 248810.

Fenetta, A., dan Keni. (2020). Pengaruh Brand Awareness dan Perceived Quality Terhadap Purchase Intention: Brand Loyalty Sebagao Variabel Mediasi. Jurnal Manajemen Bisnis Dan Kewirausahaan, 4(6), 270-275.

Hadita, H., Widjanarko, W., dan Hafizah, H. (2020). Pengaruh Kualitas Produk Smartphone Terhadap Keputusan Pembelian di Masa Pandemic Covid19. Jurnal Kajian Ilmiah, 20(3), 261-268. https://doi.org/10.31599/jki.v20i3.294

Hair, J. F. (2014). Multivariat Data Analysis 7th Edition. Pearson Prentice Hall.

Hakim, L. L. (2020). Pengaruh Brand Awareness, Brand Image Dan Customer Perceived Value Terhadap Purchase Intention. Jurnal Manajemen Bisnis Dan Kewirausahaan, 4(3), 81-86. https://www.bps.go.id/dynamictable/2018/05/18/1337/persentase-panjang-jalan-tol-yangberoperasi-menurut-operatornya-2014.html

Han, S. H., Nguyen, B., dan Lee, T. J. (2015). Consumer-Based Chain Restaurant Brand Equity, Brand Reputation, And Brand Trust. International Journal of Hospitality Management, 50(1), 84-93. https://doi.org/10.1016/j.ijhm.2015.06.010

Hultén, B. (2011). Sensory Marketing: The Multi-Sensory Brand-Experience Concept. European Business Review, 23(3), 256-273. https://doi.org/10.1108/09555341111130245

Ilyas, G. B., Rahmi, S., Tamsah, H., Munir, A. R., dan Putra, A. H. P. K. (2020). Reflective Model Of Brand Awareness On Repurchase Intention And Customer Satisfaction. Journal of Asian Finance, Economics and Business, 7(9), 427-438. https://doi.org/10.13106/JAFEB.2020.VOL7.NO9.427 
Iswandi, M., dan Ester, S. (2020). Pengaruh Kepercayaan Merek, Kesadaran Merek Dan Persepsi Kualitas Terhadap Keputusan Pembelian Pelanggan Di Supermarket Gelael Mt Haryono. Jurnal GICI, 12(1), 16-25.

Kim, Y., dan Wha, K. (2020). Effects Of Perceived Sustainability Level Of Sportswear Product On Purchase Intention: Exploring The Roles Of Perceived Skepticism And Perceived Brand Reputation. Sustainability (Switzerland), 12(20), 1-16. https://doi.org/10.3390/su12208650

Kusuma, A. H. P., Sudirman, A., Purnomo, A., Aisyah, S., Sahir, H. S., Rumondang, A., Salmiah, Halim, F., Wirapraja, A., Napitupulu, D., dan Simarmata, J. (2020). Brand Management: Esensi, Posisi dan Strategi (Cetakan 1). Yayasan Kita Menulis.

Larasari, E., Lutfi, dan Mumtazah, L. (2018). Pengaruh Brand Ambassador Dan Event Sponsorship Terhadap Purchase Intention Dengan Brand Image Sebagai Variabel Intervening. Sains: Jurnal Manajemen Dan Bisnis, 11(1), 261-280.

Madahi, A. dan Sukati, I. (2012). The Effect of External Factors on Purchase Intention amongst Young Generation in Malaysia. International Business Research, 5(8). https://doi.org/10.5539/ibr.v5n8p153

Martins, J., Costa, C., Oliveira, T., Gonçalves, R., dan Branco, F. (2019). How Smartphone Advertising Influences Consumers' Purchase Intention. Journal of Business Research, 94, 378-387. https://doi.org/10.1016/j.jbusres.2017.12.047

Maulidi, R. A. dan Yuliati, A. L. (2017). Pengaruh Tingkat Brand Awareness terhadap Minat Beli Apple iPhone. ISEI Business and Management Review, 1(1), 7-18.

Murtingsih, T., Mohammad, S. R., dan Retnaningsih, W. (2019). Influences Of Brand Experience, Brand Trust, And Brand Love Toward Purchase Intention By Word Of Mouth And Brand Loyalty As Intervening Variables In Fashion Branded In East Surabaya. Archives of Business Research, 7(9), 106-120. https://doi.org/10.14738/abr.79.6833

Putra, A. H. P. K., Ridha, A. dan As'ad, A. (2018). Celebrity Endorser Pada Jejaring Sosialinstagram Untuk Menarik Minat Pembelian Calon Konsumen. Jurnal Economic Resource, 1(1), 86-96. https://doi.org/10.33096/jer.v1i1.61

Ramaseshan, B., dan Stein, A. (2014). Connecting The Dots Between Brand Experience And Brand Loyalty: The Mediating Role Of Brand Personality And Brand Relationships. Journal of Brand Management, 21(7), 664-683. https://doi.org/10.1057/bm.2014.23 
Razak, M., Hidayat, M., Launtu, A., Kusuma Putra, A. H. P. A., dan Bahasoan, S. (2020). Antecedents And Consequence Of Brand Management: Empirical Study Of Apple's Brand Product. Journal of Asia Business Studies, 14(3), 307-322. https://doi.org/10.1108/JABS-01-2019-0030

Sanjaya, W., Asdar, M., dan Munir, A. R. (2020). The Effect of Brand Image, Brand Experience and Brand Loyalty towards Purchase IntentionOn Apple Smartphone in Makassar. Hasanuddin Journal of Business Strategy, 2(3), 74-82. https://doi.org/10.26487/hjbs.v2i3.350

Sarwono, J. (2016). Membuat Skripsi, Tesis dan Disertasi dengan Partial Least Square SEM (PLS SEM). Andi Offset.

Sata, M. (2013). Factors affecting consumer buying behavior of mobile phone devices. Mediterranean Journal of Social Sciences, 4(12), 103-112. https://doi.org/10.5901/mjss.2013.v4n12p103

Setyawan, L. J. dan Adiwijaya, M. (2018). Pengaruh Brand Awareness, Brand Experience, Dan Word of Mouth Terhadap Purchase Decision Pada Konsumen Baskhara Futsal Arena Surabaya. Agora, 6(1), 287192.

Shamim, A. dan Mohsin Butt, M. (2013). A Critical Model Of Brand Experience Consequences. Asia Pacific Journal of Marketing and Logistics, 25(1), 102-117. https://doi.org/10.1108/13555851311290957

Su, D. dan Huang, X. (2011). Research on Online Shopping Intention of Undergraduate Consumer in China--Based on the Theory of Planned Behavior. International Business Research, 4(1), 86-92. https://doi.org/10.5539/ibr.v4n1p86

Sudarso, A., Kurniullah, A. Z., Halim, F., Purba, P. B., Dewi, I. K., Simarmata, H. M., Purba, B., Sipayung, R., Sudirman, A., dan Manullang, S. O. (2019). Yayasan Kita Menulis.

Sudirman, A., Halim, F., Pakpahan, G. E., dan Sherly. (2020). Faktor-Faktor Yang Mendorong Minat Beli Smartphone Merek OPPO Dalam Kondisi Pandemi Covid 19. Seminar Nasional Manajemen, Ekonomi Dan Akuntansi, September, 1-11.

Udayana, I. B. N. (2015). the Effect of Product Innovation, Endorsements and Reputation Relation With Brand Image and Brand Awareness Toward Affirmative of Purchase Decision. Journal of Management and Business, 14(1), 13-29. https://doi.org/10.24123/jmb.v14i1.301 
Veloutsou, C. dan Guzman, F. (2017). The evolution of brand management thinking over the last 25 years as recorded in the Journal of Product and Brand Management. Journal of Product \& Brand Management, 26(1), 1-27.

Veloutsou, C. dan Moutinho, L. (2009). Brand relationships through brand reputation and brand tribalism. Journal of Business Research, 62(3), 314-322. https://doi.org/10.1016/j.jbusres.2008.05.010

Vianna, K. A., de Mesquita, J. M. C., Linhares, M. R. S., dan Moreira, P. de C. G. (2016). The Relationship Between Viral Marketing, Purchase Intention, and Brand Visibility: Study with Brazilian Customers. Academy of Marketing Science, 1(1), 229-241. https://doi.org/10.1007/9783-319-29877-1_49

Widjajanta, B., Rahayu, A., dan Salsabila, A. (2020). Pengaruh Perceived Quality dan Brand Reputation terhadap Repurchase Intention pada Reviewers Sepatu Bata Aplikasi Shopee. Strategic: Jurnal Pendidikan Bisnis, 20(1), 48-59.

Wilson, N. (2020). Analisis Pengaruh Dimensi Celebrity Endorser Terhadap Kesadaran Merek Dan Intensi Pembelian: Studi Kasus Pada Sektor Chinese-Brand Smartphone Di Indonesia. DeReMa (Development Research of Management): Jurnal Manajemen, 15(1), 15. https://doi.org/10.19166/derema.v15i1.2248

Wilson, N., Keni, K., dan Tan, P. H. P. (2019). The Effect Of Website Design Quality And Service Quality On Repurchase Intention In The E-Commerce Industry: A Cross-Continental Analysis. Gadjah Mada International Journal of Business, 21(2), 187-222. https://doi.org/10.22146/gamaijb.33665

Wong, W. H., dan Mo, W. Y. (2019). A Study of Consumer Intention of Mobile Payment in Hong Kong, Based on Perceived Risk, Perceived Trust, Perceived Security and Technological Acceptance Model. Journal of Advanced Management Science, 7(2), 33-38. https://doi.org/10.18178/joams.7.2.33-38

Wu, P. C. S., Yeh, G. Y. Y., dan Hsiao, C. R. (2011). The Effect Of Store Image And Service Quality On Brand Image And Purchase Intention For Private Label Brands. Australasian Marketing Journal, 19(1), 30-39. https://doi.org/10.1016/j.ausmj.2010.11.001 